\title{
Analysis of Taking Decision of Farmers in Choosing Rice Cultivars: Case of Pakel District, Tulungagung, Indonesia
}

\author{
Rima Dewi Oryza Sativa ${ }^{1, *}$, Jabal Tarik Ibrahim ${ }^{2}$, and Sutawi Sutawi ${ }^{3}$ \\ ${ }^{1}$ Master's Degree, Department of Agriculture Science, Postgraduate Program, \\ University of Muhammadiyah Malang, J1. Raya Tlogomas No. 246, \\ Malang 65145, East Java, Indonesia \\ ${ }^{2}$ Department of Agribusiness, Faculty of Agriculture and Animal Sciences, \\ University of Muhammadiyah Malang \\ ${ }^{3}$ Department of Animal Sciences, Faculty of Agriculture and Animal Sciences, \\ University of Muhammadiyah Malang
}

\begin{abstract}
Rice, one of the main crops in Indonesia, is the largest staple food. To increase national rice production, the government improved productivity and expanded rice fields including the attitudes and preferences of farmers to choose and use the right superior seeds. The study was conducted in Pakel Subdistrict, Tulungagung Regency, East Java Province in February 2019 to April 2019.The results showed that the farmers' decision-making process for seeds was strongly influenced by price, yield, and resistance to pests and diseases. In addition to the promotion factor, the availability of seeds at the trader and product quality determines the stage of purchasing the seeds to be planted.
\end{abstract}

Keyword: Increase rice productivity, preference, price, promotion, seed

\section{Introduction}

Rice is one of the main crops in Indonesia which produces the largest staple food. Indonesia is the country with the third largest rice consumption after China and India. This is supported by more than $90 \%$ of Indonesian people consuming rice every day thus instability in food handling issues, especially rice will have an impact on various aspects of life such as social conditions, economic stability, employment, and others. The government is always trying to improve food security through rice self-sufficiency. Therefore, rice production needs to be increased thus it can be met from domestic production (selfsufficiency). Many modern rice varieties (MVs) have been released but only a few have been widely adopted by farmers [1].

Efforts to increase national rice production are by increasing productivity and expanding the region. The technology used is the use of superior seeds. The use of quality seeds is the first key to success in rice farming. Varieties or cultivars are important technological components that have a large contribution in increasing agricultural

\footnotetext{
* Corresponding author: rimadewioryza@gmail.com
} 
production and income [2]. This technological component is very instrumental in changing the rice farming system, from subsystem to commercial rice farming [3].

Rice superior cultivars themselves have developed in Indonesia since before 1970. In general the names of these superior cultivars use river names in Indonesia including: 'Bengawan', 'Brantas', 'Citarum', and others. Food self-sufficiency, especially rice, from 2007 to 2016 the Agricultural Research and Development Agency through the Indonesian Rice Research Center (ICRR) has released various New Superior Varieties (VUB) for agroecosystem rice cultivation. Starting in 2008, the naming of New Superior Varieties (VUB) no longer uses the name of the river in Indonesia but uses a new name, called INPA for inbred rice and HIPA for hybrid rice.

Farmer decision making also influences the development of high yielding varieties. This is related to the nature possessed by superior cultivars [5]. Farmers generally want highyielding varieties, good taste (specifically for the region), early maturity, proper height of plants, and resistant to pests and major diseases such as brown plant hopper (Nilaparvata lugens Stål, 1854), tungro (rice tungro bacilliform virus and rice tungro spherical virus).

In an effort to increase national rice productivity, the role of innovation in superior variety technology is very large. Around $90 \%$ of the superior cultivars used by farmers in Indonesia today are cultivars produced by the ICRR. The use of improved cultivars by farmers in addition to increasing national rice production, also has a multiplier effect on the national economy, including the development of bioindustrial farming systems, the seed industry, improving farmers' welfare, opening jobs and others, estimated at IDR $1.5 \times 10^{12} \mathrm{yr}^{-1}[5]$.

Farmers are the main actors in the agricultural business. Therefore the attitudes and characteristics of rice farmers towards seed varieties are very important, because farmers have a dual role, as a producer of rice and consumers of seed products [6]. As producers, farmers must be able to meet market demand thus farmers' preferences for seed varieties cannot be separated from meeting the interrelated market desires. Although many new varieties have been discovered and introduced to farmers, if they do not meet the criteria of farmers as users, farmers will return to using old varieties [7].

Research aims to describe the characteristics of farmers based on the selected rice cultivars to be planted in their paddy fields and the decision-making process of farmers in choosing rice cultivars, analyzing the factors that influence decision making in selecting rice cultivars for farmers in Pakel District, Tulungagung Regency, Indonesia.

This research provides information about the decision making process and the factors that influenced in choosing rice cultivars. Research information can be used as a reference in policy making by the government in developing rice cultivars, for seed companies it can be used as a reference in marketing, and can be used as literature for other researchers.

\section{Methods}

The method used descriptive tabulation, Customer Satisfaction Index (CSI) and Multiple Linear Analysis. Descriptive analysis aimed to describe the various data collected without intending to make general conclusions or generalizations. Descriptive analysis according to data is in the form of tables and grouped based on the same answer Tanty et al. [8]. The results obtained were presented based on the number of respondents, and the largest percentage is the dominant factor of the analyzed variables. The Customer Satisfaction Index is used to measure satisfaction with product performance and desired attributes. Multiple linear regression is one of the statistical data analysis techniques that is often used to study the relationship between several variables and predict a variable [9]. 


\section{Results}

\subsection{Characteristics of farmers}

The characteristics of farmers in this study were $50 \mathrm{yr}$ to $60 \mathrm{yr}$, most of the respondents' education was primary school. Farming was the main occupation of the respondent farmer. The results ranged from $4 \mathrm{tha}^{-1}$ to $7 \mathrm{t} \mathrm{ha}^{-1}$. The farmers' decision-making process for seeds was strongly influenced by price, yield, and resistance to pests and diseases [10]. In addition to the promotion factor, the availability of seeds at the trader and product quality determined the stage of purchasing the seeds to be planted.

\subsection{Customer satisfaction index}

The level of importance and the level of performance of each attribute by calculating the Customer Satisfaction Index (CSI) [11]. In Table 1, the CSI value was $76.42 \%$ (0.764 2). This value ranged from 0.60 to 0.80 which means farmers are satisfied with the performance attributes found in superior variety seeds. In subsequent studies the satisfaction index must be increased to close to $100 \%$.

\subsection{Analysis of testing requirements}

\subsubsection{The 'Ciherang', 'Logawa', and 'Inpari' normality test}

\section{i. Classic assumption test}

In the Kolmogorof Smirnov table, cultivars produce asymptotic significance $\geq 0.05$. The normality test was on a normal graph, spreading points around a diagonal line and following a diagonal line. The histogram pattern showed that the distribution pattern was close to normal, so it can be concluded that the data is normally distributed and the regression model meets normality.

\section{ii. Heteroskedasticity test}

On the plot graph the prediction value of the variable was bound to the residual, random distribution of points above or below the zero point of the $\mathrm{Y}$ axis, then it is concluded that there is no heteroscedasticity.

\section{iii. Multicollinearity test}

The results of the Variance Inflation Factor (VIF) value using SPSS, the VIF value $<10$ and tolerance value $>0.10$. It can be concluded that there is no multicollinearity between the independent variables.

\subsubsection{The 'Ciherang' multiple linear model}

A simple linear regression model is used to test the effect of variables $\mathrm{X} 1, \mathrm{X} 2, \mathrm{X} 3$ on $\mathrm{Y}$ 
Table 1. The 'Ciherang' multiple linear analysis

\begin{tabular}{|c|c|c|c|c|c|c|}
\hline \multirow{2}{*}{ Model } & \multicolumn{2}{|c|}{$\begin{array}{c}\text { Unstandardized } \\
\text { coefficients }\end{array}$} & $\begin{array}{c}\text { Standardized } \\
\text { coefficients }\end{array}$ & \multirow{2}{*}{ t } & \multirow{2}{*}{ Sig. } & $\begin{array}{c}\text { Collinearity } \\
\text { statistics }\end{array}$ \\
\cline { 2 - 6 } & $\mathbf{B}$ & $\begin{array}{c}\text { Std. } \\
\text { error }\end{array}$ & Beta & & & Tolerance \\
\hline Constant & 28.022 & 5.154 & & 5.437 & 0.000 & \\
\hline Price & -0.272 & 0.523 & -0.078 & -0.521 & 0.605 & 0.819 \\
\hline Where to get seeds & 0.894 & 0.370 & 0.369 & 2.417 & 0.020 & 0.785 \\
\hline Promotion & 1.056 & 0.685 & 0.214 & 1.543 & 0.130 & 0.954 \\
\hline
\end{tabular}

Based on the results of data processing using SPSS, a constant coefficient value of 28.022, grain price coefficient of -0.272 , place coefficient of getting grain 0.894 , promotion coefficient of 1.056. Then the regression equation can be Equation (1):

$$
\mathrm{Y}=28.022-0.272 \mathrm{X} 1+0.894 \mathrm{X} 2+1.056 \mathrm{X} 3
$$

\section{i. The 'Ciherang' determination test}

The coefficient of determination (R2) from the results of multiple regression showed that the dependent variable (product) was influenced by the independent variable (price, place to get seeds, promotion).

Table 2. The 'Ciherang' determination test

\begin{tabular}{|c|c|c|c|c|}
\hline Model & R & R square & Adjusted R square & Std. error of the estimate \\
\hline & $.441^{\mathrm{a}}$ & .195 & 0.140 & 3.20623 \\
\hline
\end{tabular}

The test resulted in a coefficient of determination (R2) of 0.195 or $19.5 \%$. This showed that $19.5 \%$ of products were influenced by price, place to get seeds, promotion. While $80.5 \%$ is influenced by other variables not included in this research model.

\section{ii. The 'Ciherang't test}

$\mathrm{t}$ test is done by comparing the t-value obtained, with a significance level of 0.05 with a level of freedom $(\mathrm{df})=\mathrm{nk}=48-4=44$, with this provision the table 2015 is obtained.

The conclusion:

A. Price (X1)

$\mathrm{H} 0$ is accepted and Ha is rejected, so it can be concluded that the price variable partially has no effect on the product variable. As for the combined variables, price affects the product.

B. Place (X2)

$\mathrm{HO}$ is accepted and $\mathrm{Ha}$ is accepted, so it can be concluded that the place variable partially influences the product variable. Whereas the shared place variable affects the product.

C. Promotion (X3)

$\mathrm{HO}$ is accepted and $\mathrm{Ha}$ is rejected, so it can be concluded that the promotion variable partially has no effect on the product variable. Whereas the joint promotion variable affects the product. 


\section{iii. The 'Ciherang' $F$ test}

ANOVA test using SPSS version 19, the number of $F$ was 3.546. Based on table $F$ with a significance level $(\mathrm{a})=5 \%$, it is known that table $\mathrm{T}$ with dfl $=\mathrm{k}-1=4-1=3$ and df $2=n k=48-4=44$, then $F$ table $(\mathrm{dfl})(\mathrm{df} 2)=2.816$. Based on the calculation results obtained $\mathrm{F}$ count $=3.546$ while $\mathrm{F}$ table $=2.816$, then $\mathrm{F}$ count $>\mathrm{F}$ table. If seen from the significance value in table $0.022<0.05$ this showed that the price, place to get seeds, and promotions affect the product.

Table 3. The 'Ciherang' F test

\begin{tabular}{|l|c|c|c|c|c|}
\hline Model & Sum of squares & df & Mean square & F & Sig. \\
\hline Regression & 109.352 & 3 & 36.451 & 3.546 & $.022^{\mathrm{b}}$ \\
\hline Residual & 452.315 & 44 & 10.280 & & \\
\hline Total & 561.667 & 47 & & & \\
\hline
\end{tabular}

\subsubsection{The 'Logawa' multiple linear model}

Table 4. The 'Logawa' multiple linear analysis

\begin{tabular}{|c|c|c|c|c|c|r|}
\hline \multirow{2}{*}{ Model } & \multicolumn{2}{|c|}{$\begin{array}{c}\text { Unstandardized } \\
\text { coefficients }\end{array}$} & $\begin{array}{c}\text { Standardized } \\
\text { coefficients }\end{array}$ & \multirow{2}{*}{ Sig. } & $\begin{array}{c}\text { Collinearity } \\
\text { statistics }\end{array}$ \\
\cline { 2 - 4 } & $\mathbf{B}$ & $\begin{array}{c}\text { Std. } \\
\text { Error }\end{array}$ & Beta & & & Tolerance \\
\hline Constant & 20.353 & 5.134 & & 3.964 & 0.000 & \\
\hline Price & 0.517 & 0.634 & 0.113 & 0.816 & 0.419 & 0.810 \\
\hline Location & 0.618 & 0.309 & 0.275 & 1.997 & 0.052 & 0.812 \\
\hline Promotion & 2.250 & 0.583 & 0.481 & 3.858 & 0.000 & 0.993 \\
\hline
\end{tabular}

Based on the results of data processing using SPSS, a constant coefficient value of 20.353 , grain price coefficient of 0.517 , place coefficient of getting grain 0.618 , promotion coefficient of 2.250. Then the regression equation can be Equation (2):

$\mathrm{Y}=20.353+0.517 \mathrm{X} 1+0.618 \mathrm{X} 2+2.250 \mathrm{X} 3$

\section{i. The 'Logawa' determination test}

The coefficient of determination (R2) from the results of multiple regression showed the dependent variable (product) is influenced by the independent variable (price, place to get seeds, promotion).

Table 5. The 'Logawa' determination test

\begin{tabular}{|c|c|c|c|c|}
\hline Model & R & R square & $\begin{array}{c}\text { Adjusted R } \\
\text { square }\end{array}$ & $\begin{array}{c}\text { Std. error of } \\
\text { the estimate }\end{array}$ \\
\hline & $0.567^{\mathrm{a}}$ & 0.321 & 0.275 & 3.35064 \\
\hline
\end{tabular}

The results of the coefficient of determination (R2) were 0.321 or $32.1 \%$. This showed that $32.1 \%$ of the products were influenced by price, place to get seeds, promotion, while $67.9 \%$ was influenced by other variables not included in this study. 


\section{ii. The 'Logawa' t test}

Degrees of freedom $(\mathrm{df})=\mathrm{n}-\mathrm{k}=48-4=44$, with this provision a Table of 2.015 was obtained.

The conclusion:

i. Price $(\mathrm{X} 1)$

$\mathrm{HO}$ is accepted and $\mathrm{Ha}$ is rejected, so it can be concluded that the price variable partially has no effect on the product variable. Whereas for the joint variable Price affects the product.

ii. Place $(\mathrm{X} 2)$

$\mathrm{HO}$ is accepted and $\mathrm{Ha}$ is rejected, so it can be concluded that the place variable partially has no effect on the product variable. Whereas for shared place variables affect the product.

iii. Promotion (X3)

$\mathrm{HO}$ is accepted and Ha is accepted, so it can be concluded that the promotion variable partially influences the product variable. Whereas for joint promotion variables affect the product.

\section{iii. The 'Logawa' $\mathbf{F}$ test}

According to ANOVA test using SPSS version 20, the F count was 6.946. Based on table F with a significance level $(a)=5 \%$, it is known that $\mathrm{T}$ table with $\mathrm{dfl}=\mathrm{k}-1=4-1=3$ and $\mathrm{df} 2=\mathrm{n}-\mathrm{k}=48-4=44$, then $\mathrm{F}$ table $(\mathrm{dfl})(\mathrm{df} 2)=2.816$. Based on the calculation results obtained $\mathrm{F}$ count $=6.946$ while $\mathrm{F}$ table $=2.816$, then $\mathrm{F}$ count $>\mathrm{F}$ table. If seen from the significance value in the table $0.001<0.05$ this showed that the price, place to get seeds, and promotions affected the product.

Table 6. The 'Logawa' F test

\begin{tabular}{|l|c|c|c|c|c|}
\hline \multicolumn{1}{|c|}{ Model } & Sum of squares & df & Mean square & F & Sig. \\
\hline Regression & 233.938 & 3 & 77.979 & 6.946 & $0.001^{\mathrm{b}}$ \\
\hline Residual & 493.979 & 44 & 11.227 & & \\
\hline Total & 727.917 & 47 & & & \\
\hline
\end{tabular}

\subsubsection{The 'Inpari' multiple linear models}

Table 7. The 'Inpari' multiple linear analysis

\begin{tabular}{|l|c|c|c|c|c|c|}
\hline \multirow{2}{*}{ Model } & \multicolumn{2}{|c|}{$\begin{array}{c}\text { Unstandardized } \\
\text { coefficients }\end{array}$} & $\begin{array}{c}\text { Standardized } \\
\text { coefficients }\end{array}$ & \multirow{2}{*}{ S } & \multirow{2}{*}{ Sig. } & $\begin{array}{l}\text { Collinearit } \\
\text { y statistics }\end{array}$ \\
\cline { 2 - 4 } \cline { 3 - 7 } & $\mathbf{B}$ & $\begin{array}{c}\text { Std. } \\
\text { Error }\end{array}$ & Beta & & & Tolerance \\
\hline Constant & 26.136 & 4.876 & & 5.360 & 0.000 & \\
\hline Price & 0.449 & 0.588 & 0.106 & 0.763 & 0.450 & 0.886 \\
\hline Location & 0.960 & 0.317 & 0.434 & 3.026 & 0.004 & 0.836 \\
\hline Promotion & 0.228 & 0.586 & 0.053 & 0.390 & 0.699 & 0.935 \\
\hline
\end{tabular}

Based on the results of data processing using SPSS, a constant coefficient value of 26.136, grain price coefficient 0.449 , grain coefficient obtained 0.960 grain, promotion coefficient 0.228 . Then the regression equation can be Equation (3): 
$\mathrm{Y}=26.136+0.449 \mathrm{X} 1+0.960 \mathrm{X} 2+0.228 \mathrm{X} 3$

\section{i. The 'Inpari' determination test}

The coefficient of determination (R2) from the results of multiple regression showed the dependent variable (product) was influenced by the independent variable (price, place to get seeds, promotion).

Table 8. The 'Inpari' determination test

\begin{tabular}{|l|c|r|r|r|}
\hline Model & R & R square & Adjusted R square & $\begin{array}{c}\text { Std. error of the } \\
\text { estimate }\end{array}$ \\
\hline & $0.493^{\mathrm{a}}$ & 0.243 & 0.192 & 3.39783 \\
\hline
\end{tabular}

Test results for the coefficient of determination (R2) of 0.243 or $24.3 \%$. This showed that $24.3 \%$ of products were influenced by price, place to get seeds, promotion, while 75.7 were influenced by other variables outside this study.

\section{i. The 'Inpari' t test}

The conclusion:

i. Price (X1)

$\mathrm{H} 0$ is accepted and Ha is rejected, so it can be concluded that the price variable partially has no effect on the product variable. Whereas for the joint variable Price affects the product.

ii. Place (X2)

$\mathrm{HO}$ is accepted and $\mathrm{Ha}$ is accepted, so it can be concluded that the place variable partially influences the product variable. Whereas for shared place variables affect the product.

iii. Promotion (X3)

$\mathrm{HO}$ is accepted and $\mathrm{Ha}$ is rejected, so it can be concluded that the promotion variable partially has no effect on the product variable. Whereas for joint promotion variables affect the product.

\section{ii. The 'Inpari' $\mathbf{F}$ Test}

ANOVA test using SPSS version 20, the F count was 4.720. Based on table F with a significance level $(\mathrm{a})=5 \%$, it is known that $\mathrm{T}$ table with $\mathrm{dfl}=\mathrm{k}-1=4-1=3$ and $\mathrm{df} 2=\mathrm{n}-\mathrm{k}=48-4=44$, then $\mathrm{F}$ table $(\mathrm{dfl})(\mathrm{df} 2)=2.816$. Based on the calculation results obtained F count $=4.720$ while $\mathrm{F}$ table $=2.816$, then $\mathrm{F}$ count $>\mathrm{F}$ table. If seen from the significance value in the table $0.006<0.05$ this showed that the price, place to get seeds, and promotions affect the product.

Table 9. The 'Inpari' F Test

\begin{tabular}{|l|l|l|l|l|l|}
\hline Model & Sum of squares & df & Mean square & F & Sig. \\
\hline Regression & 163.488 & 3 & 54.496 & 4.720 & $0.006^{\mathrm{b}}$ \\
\hline Residual & 507.992 & 44 & 11.545 & & \\
\hline Total & 671.479 & 47 & & & \\
\hline
\end{tabular}




\section{Discussion}

The results of the $\mathrm{F}$ test showed that price, place, promotion jointly affected the product. Result $t$ test indicated the price did not affect the product. This explained that the price set for a particular product did not have a positive effect on the buying interest of the respondent farmers because rice seed is a prestige product that more reasonably the price the buying interest of the respondent farmers. While the current promotion of rice seeds has not yet fully attracted the interest of farmers, the reason being that promotion is limited to banners, advertisements, without any direct promotion to farmers [5]. Moreover, the places influenced on products because respondents tend to look for products that are easily accessible through kiosks or farmer groups. This showed that the equitable distribution of products to farmers is needed.

\section{Conclusion}

The farmers' decision-making process for seeds was strongly influenced by price, yield, and resistance to pests and diseases. In addition to promotion factors, the availability of seeds at traders and product quality determine the stage of purchasing seeds to be planted. Based on CSI calculations, farmers were satisfied with the performance of superior seed attributes.

\section{References}

1. A.G. Laborte, N.C. Paguirigan, P.F. Moya, A. Nelson, A.H. Sparks, G.B. Gregorio. Plos One 10,8: e0136562(2015). https://doi.org/10.1371/journal.pone.0136562

2. M. Mwangi, S. Kariuki. J. Econ. Sustain. Dev. 6,5:208-216(2015). https://www.iiste.org/Journals/index.php/JEDS/article/viewFile/20710/21632

3. M.A. Altieri, C.I. Nicholls, A. Henao, M.A. Lana. Agron. Sustain. Dev. 35:869-90(2015).

doi: 10.1007/s13593-015-0285-2. or https://link.springer.com/article/10.1007/s13593015-0285-2

4. W. Naivit, L.C. Page, G. Trebuil, N. Gajaseni. Environ. Model. Softw. 25,11:1345-1358(2010).

https://www.sciencedirect.com/science/article/pii/S1364815210000381

5. S. Rahayu, Y.P. Wanita, M. Kobarsih. Agrin. 15,1:36-44(2011). [in Bahasa Indonesia]. http://garuda.ristekbrin.go.id/documents/detail/747295

6. M. Mehar, A. Panda, T. Yamano. Asian J. Agric. Dev. 14,1:17-36(2017). https://ageconsearch.umn.edu/record/259241/

7. S.K. Killenga, P. Tongoona, J. Derera, Z. Kanyeka. Int. J. Dev. Sust. 3,6:12571271(2014). https://isdsnet.com/ijds-v3n6-2.pdf

8. H. Tanty, R.D. Bekti, A. Rahayu. Jurnal Mat. Stat., 13, 2:97-104(2013). [in Bahasa Indonesia].

https:/www.google.com/url?sa=t\&rct=j\&q=\&esrc=s\&source=web\&cd=\&cad=rja\&ua ct=8\&ved=2ahUKEwi96snGpOPrAhVIVH0KHTOnCmkQFjAAegQIBRAB\&url=htt p\%3A\%2F\%2Flibrary.binus.ac.id\%2FeColls\%2FeJournal\%2F04_Heruna\%2C\%2520 Rokhana\%2C\%2520Anita.pdf\&usg=AOvVaw02kVGxmPJ8NPzBV84zBdOw

9. K.A. Garrett, G.A. Forbes, S. Savary, P. Skelsey, A.H. Sparks, C. Valdivia C, et al. Plant. Path. 60,1:15-30(2011).

https://bsppjournals.onlinelibrary.wiley.com/doi/abs/10.1111/j.1365$\underline{3059.2010 .02409 . \mathrm{x}}$ 
10. K.A. Garrett, G.A. Forbes, S. Savary, P. Skelsey, A.H. Sparks, C. Valdivia, et al. Plant Disease. 95,10:1204-1216(2011). https://apsjournals.apsnet.org/doi/pdf/10.1094/PDIS-04-11-0316

11. S. Nikou, H. Selamat, R.C.M. Yusoff, M.M. Khiabani. Int. J. Adv Sci. Technical Res. 6,6:29-46(2016).

https://www.researchgate.net/publication/311607113_Service_Quality_Customer_Sati sfaction_and_Customer_Loyalty_A_Comprehensive_Literature_Review_1993-2016 